\title{
Hydroponic lettuce production in different concentrations and flow rates of nutrient solution
}

Gláucio da C Genuncio; Marcelle Gomes; Anderson Claiton Ferrari; Nidia Majerowicz; Everaldo Zonta UFRRJ, Depto. Solos, BR 465, km 7, 23890-000 Seropédica-RJ; glauciogenuncio@gmail.com; mazerop@hotmail.com; anderson.rural@ hotmail.com; nidia@ufrrj.br; ezonta@ufrrj.br

\begin{abstract}
The objective of this study was to evaluate the accumulation of fresh weight of hydroponic lettuce in terms of ionic concentrations and flow rates of nutrient solution. This work consisted of three experiments in NFT hydroponic system, conducted between July and September 2006. Lettuce cultivars Lucy Brown, Izabela and Veneza were grown in different ionic concentrations of the 100, 75 and $50 \%$ and flow rates of $1.50,1.00$ and $0.75 \mathrm{~L} \mathrm{~min}^{-1}$. Fresh weight gains were observed for Lucy Brown when grown on $100 \%$ of the ion concentration and a flow rate of nutrient solution of $1.0 \mathrm{~L} \mathrm{~min}^{-1}$. Greater fresh mass was observed for cvs. Izabela and Veneza under the flow rate of $1.5 \mathrm{~L} \mathrm{~min}^{-1}$. A general analysis of the data allows us to conclude that the application of nutrient solution at a flow rate of $1.5 \mathrm{~L} \mathrm{~min}^{-1}$, as well as $100 \%$ of the ionic concentration is effective to increase the fresh weight of the aerial part of cvs. Lucy Brown, Izabela and Veneza when grown in hydroponics.
\end{abstract}

Keywords: Lactuca sativa, nutritional management, production, ion concentration.

\section{RESUMO}

Produção de cultivares de alface em sistema NFT variando concentração e vazão da solução

O objetivo deste trabalho foi avaliar o acúmulo de massa fresca em cultivares de alface hidropônica em função de concentrações iônicas e de vazões de solução nutritiva. $O$ trabalho consistiu em três experimentos em sistema hidropônico NFT, conduzidos entre julho e setembro de 2006. Cultivares de alface Lucy Brown, Izabela e Veneza foram crescidas em concentrações iônicas de 100, 75 e $50 \%$ e vazões de 1,$50 ; 1,00$ e $0,75 \mathrm{~L} \mathrm{~min}^{-1}$. Ganhos de massa fresca foram observados para Lucy Brown quando cultivada a $100 \%$ da concentração iônica e a uma vazão de solução nutritiva acima de 1,0 $\mathrm{L} \mathrm{min}^{-1}$. Para Izabela e Veneza maiores massas frescas foram observadas em vazão de $1,5 \mathrm{~L} \mathrm{~min}^{-1}$ e $100 \%$ de concentração iônica. Uma análise geral dos dados nos permite concluir que a aplicação da solução nutritiva a uma vazão de $1,5 \mathrm{~L} \mathrm{~min}^{-1}$, assim como $100 \%$ da concentração iônica é eficiente para acréscimos de massa fresca de parte aérea para cultivares Lucy Brown, Izabela e Veneza quando cultivadas em hidroponia.

Palavras-chave: Lactuca sativa, manejo nutricional, produção, concentração iônica.

(Recebido para publicação em 26 de setembro de 2011; aceito em 4 de julho de 2012)

(Received on September 26, 2011; accepted on July 4, 2012)

$\mathrm{I}_{\mathrm{c}}^{\mathrm{n}}$ Brazil, six groups of lettuce are cultivated. Among them, some stand out, such as the head, crisp and loose-leaf groups (Luz et al., 2006; Filgueira, 2008). The cultivation of these groups in hydroponics may be an interesting alternative since it provides the producer the possibility of an effective interference in environmental and nutritional conditions of this system. The control over the wind, rain and sunlight, as well as the nutrient supply in appropriate levels to the crop growth, decrease the losses in yield and increase the quality of hydroponic lettuce (Furlani et al., 1999).

On the other hand, for an effective nutritional management and, consequently, an increase in hydroponic lettuce yield, it is indispensable the appropriate control of the nutrient solution. Among the factors to be controlled are electrical conductivity $(\mathrm{CE}), \mathrm{pH}$, temperature and oxygen concentration, as well as the period of time and the flow of the solution available to the plant roots during the crop cycle (Furlani et al., 1999). Values of $\mathrm{pH}$ close to $6.0,27^{\circ} \mathrm{C}$ of temperature and $12 \mathrm{ppm}$ of $\mathrm{O}_{2}$ are used by producers in several regions of Brazil. However, for the variables $\mathrm{CE}$, time and irrigation flow rate, it is necessary to set parameters, because of the great variability noticed at the producer level. Generally speaking, for lettuce the values can range from 0.9 to $2.5 \mathrm{dS} \mathrm{m}^{-1}$ of CE (Furlani et al., 1999; Schmidt et al., 2001; Rodrigues, 2002), 36-48 irrigation cycles of 15 minutes a day and flow rate from 1.2 to $2.0 \mathrm{~L} \mathrm{~min}^{-1}$ (Furlani et al., 1999; Helbel Júnior et al., 2007).

The aim of this research was to evaluate the effect of the flow rate of the nutrient solution and the $\mathrm{CE}$ concentration (measured through the ionic strength of the solution) over the accumulation of fresh mass of the aboveground part and roots in different cultivars of hydroponic lettuce.

\section{MATERIAL AND METHODS}

This work consisted of three experiments in hydroponic system which were carried out, from July to September, 2006, in the Universidade Federal Rural do Rio de Janeiro, in Seropedica, Rio de Janeiro state,

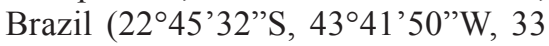
$m$ altitude).

The greenhouse used was of an arch shape, with $4.20 \mathrm{~m}$ height and 5.30 $\mathrm{m}$ height at the central span, covered with low density polyethylene film, 
additivated with 5\% light diffusor and 150 micron thickness and lateral parts protected with white anti-aphid screen (mesh $=0.64 \times 0.20 \mathrm{~mm}$ ). The maximum and the minimum temperatures were registered daily, as well as the air relative humidity (UR) inside the greenhouse, at 9 a.m. and 3 p.m., using maximum and minimum thermometers and a direct reading hygrometer. The average of maximum and minimum temperatures $\left({ }^{\circ} \mathrm{C}\right)$ and UR\% were 32.3 ; 18.6 and 59.1 , respectively, for the period when the experiment was in progress.

The cultivars used were Lucy Brown (Seminis), Izabela and Veneza Roxa (Sakata). The seeds were germinated in dark chamber, in polypropylene tray of 200 cells filled with coconut fiber. After germination, the seedlings were grown in a greenhouse, nourished with nutrient solution of Furlani et al (1999) modified for iron (40 $\mathrm{mg} \mathrm{L}^{-1}$ of Fe-EDDHA 6\%) and diluted to $1 / 4$ of the ion concentration up to 15 days after sowing. At 15 days after sowing, the seedlings (bare root) were transplanted to the cultivation channels, $6 \mathrm{~m}$ long, spaced $0.23 \mathrm{~m}$ between profiles, $0.25 \mathrm{~m}$ between plants and 4\% slope.

For the composition of the nutrient solution, the following doses of fertilizers were used, in $\mathrm{mg} \mathrm{L}^{-1}: 750$ calcium nitrate; 500 potassium nitrate; 150 monoammonium phosphate; 400 magnesium sulfate; 0.15 copper sulfate; 0.50 zinc sulfate; 1.50 manganese sulfate; 1.50 boric acid; 0.15 sodium molybdate and $40 \mathrm{Fe}-\mathrm{EDDHA}-6 \%$ for a $100 \%$ ionic concentration. The $50 \%$ and $75 \%$ of ionic concentration treatments were obtained through the dilution of the solution with total ionic concentration. The electric conductivities observed in the solutions with $100 \%, 75 \%$ and $50 \%$ of ionic concentration were 1.80 , 1.39 and $0.92 \mathrm{dS} \mathrm{m}^{-1}$, respectively. The replacement of nutrients was performed at the depletion in $20 \%$ of CE of the initial solutions, using the stock solution according to Furlani et al. 1999). At 27 and 39 days after sowing, the solutions were renewed. The adjusting of the $\mathrm{pH}$ of the solution was carried out daily, applying solutions of $0.1 \mathrm{~mol} \mathrm{~L}^{-1}$ of $\mathrm{KOH}$ or $\mathrm{HCl}$ to keep $\mathrm{pH}$ between 6.0 and 6.5 .
During the day, from 6 a.m. to 6 p.m., the circulation of the nutrient solution was done for 15 minutes every 15 minutes (48 cycles). During the night, the circulation was for 15 minutes every 3 hours ( 4 cycles). Irrigation was performed through bench individual systems and pumped by $32 \mathrm{~W}$ of power. The volume of the reservoir was 150 $\mathrm{L}$, providing a ratio of $1 \mathrm{~L}_{\text {plant }}{ }^{-1}$, approximately.

Experiment 1 was carried out in a completely randomized design, $3 \times 3$ factorial in three flow rates $(1.50 ; 1.00$ and $0.75 \mathrm{~L} \mathrm{~min}^{-1}$ ) and three cycles of 30-day cultivation (July, August and September), nine replications and twelve plants of cultivar Lucy Brown per replication. It is noteworthy that the nutrient solution used in this experiment contained $100 \%$ of ionic concentration.

Experiment 2 was carried out in July, in blocks at random, $3 \times 3 \times 2$ factorial scheme (three flow rates, three ionic concentrations and two cultivars), arranged in split plots, in which the flow rates were the main plots and the factorial $3 \times 2$ (three ionic concentrations and two cultivars) the sub plots, in a total of three replications (blocks); each replication contained three plants of each cultivar (Lucy Brown and Izabela). The nutrient solution flow rates were $\mathrm{V} 1=1.50 ; \mathrm{V} 2=1.00$ and $\mathrm{V} 3=0.75 \mathrm{~L}$ $\mathrm{min}^{-1}$ and the ionic concentrations were 100, 75 and $50 \%$.

Experiment 3 was carried out in September in randomized blocks, $3 \times 2$ factorial scheme (three flow rates of nutrient solution and two cultivars),

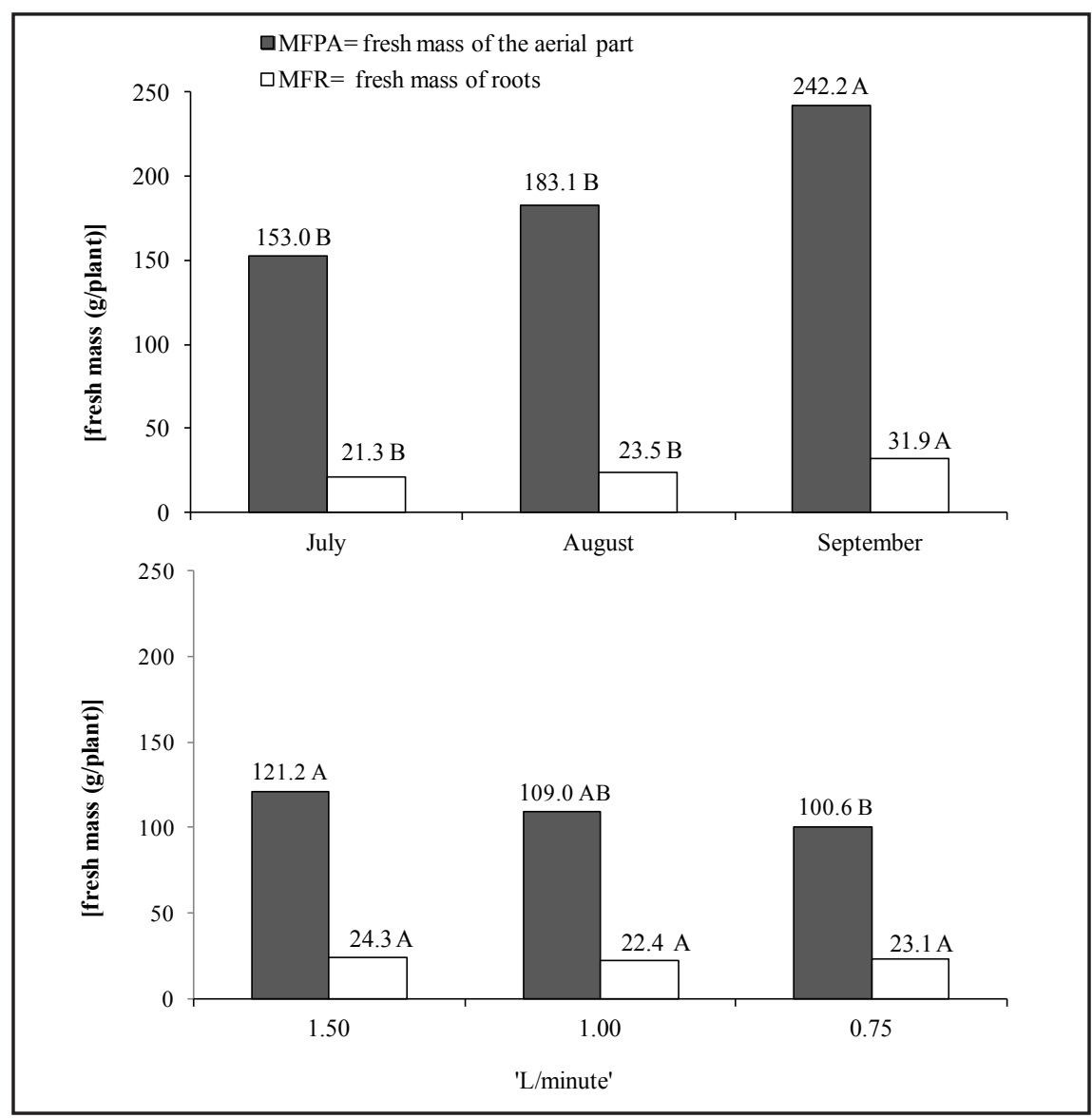

Figure 1. Fresh weight of aerial part and roots of lettuce (g plant $\left.{ }^{-1}\right)$ (cv. Lucy Brown), grown in hydroponics during three cycles of culture from July to September 2006 and three flow rates of nutrient solution (massa fresca de parte aérea e raiz de alface americana ( $\mathrm{g}$ planta ${ }^{-1}$ ) (cv. Lucy Brown), cultivada em hidroponia durante três ciclos de cultivo, nos meses de julho a setembro de 2006 e em três vazões de solução nutritiva). *Means followed by the same letter did not differ by Tukey test (para cada característica, médias seguidas pela mesma letra não diferem pelo teste de Tukey). Seropédica, UFRRJ, 2006. 
with eight replications (blocks) and four plants of each cultivar per block. The flow rates used were: $\mathrm{V} 1=1.50$; $\mathrm{V} 2=1.00$ and $\mathrm{V} 3=0.75 \mathrm{~L} \mathrm{~min}^{-1}$ and the cultivars were Lucy Brown and Veneza. The nutritient solution used in this experiment contained $100 \%$ of ionic concentration.

The plants were harvested between 7 and 9 a.m., at 45 days after sowing in all experiments. In these plants fresh mass of the aboveground part and roots were quantified. The data of all experiments were evaluated using the statistical program $\mathrm{SAEG}^{\circledR}$ v. 8.0 (SAEG, 2000), by ANOVA and Tukey test at $5 \%$.

\section{RESULTS AND DISCUSSION}

No significant interaction was observed among the factors cultivation cycles and tested flow rates in experiment 1 ; however, a greater accumulation of fresh mass in the aboveground part and roots was observed for 'Lucy Brown' in September. 'Lucy Brown' also accumulated greater average fresh mass (cycles and cultivation) of the aboveground part in flow rates higher than $1 \mathrm{~L} \mathrm{~min}^{-1}$ (Figure 1). The results suggest a decrease in the cultivation cycle of head lettuce cultivated in hydroponics from the increase of $0.9^{\circ} \mathrm{C}$ and $8.1 \%$ in minimum temperature and $\mathrm{UR} \%$ under protected cultivation, verified between July and September and associated with the flow rates of nutrient solution higher than $1 \mathrm{~L} \mathrm{~min}^{-1}$ (Figure 1).

Similar results to ones in experiment 1 , related to the flow rate factors and ionic concentration of nutrient solution, were observed for cultivar Lucy Brown in experiment 2. Higher accumulation of fresh mass in the aboveground part was observed for interactions flow rates of 1.5 and $1.0 \mathrm{~L} \mathrm{~min}^{-1}$ and total ionic concentration (Table 1). 'Izabela' showed higher accumulation of fresh mass of the aboveground part only in the interaction flow rate of $1.5 \mathrm{~L} \mathrm{~min}^{-1}$ and total ionic concentration (Table 1).

The fresh mass accumulation of 'Lucy Brown' roots was higher in treatments with total ionic concentration, regardless of flow rate, as well as in

Table 1. Fresh weight of aerial part and roots $\left(\mathrm{g}\right.$ plant $\left.{ }^{-1}\right)$ of lettuce cvs. Lucy Brown and Izabela, grown in hydroponics at different flow rates and ion concentrations of the nutrient solution, in July 2006 (massa fresca de parte aérea e raiz (g planta $\left.{ }^{-1}\right)$ de alface, cvs. Lucy Brown e Izabela, cultivada em hidroponia em diferentes vazões e concentrações iônicas da solução nutritiva, em julho de 2006). Seropédica, UFRRJ, 2006.

\begin{tabular}{|c|c|c|c|c|c|c|}
\hline \multicolumn{7}{|c|}{ Lucy Brown } \\
\hline \multirow[b]{2}{*}{$\mathrm{L} \mathrm{min}^{-1}$} & \multicolumn{3}{|c|}{ Fresh weight of aerial part } & \multicolumn{3}{|c|}{ Fresh weight of roots } \\
\hline & $100 \%$ & $75 \%$ & $50 \%$ & $100 \%$ & $75 \%$ & $50 \%$ \\
\hline 1.50 & $163.7 \mathrm{Aa}$ & $125.9 \mathrm{Ab}$ & $42.6 \mathrm{Ac}$ & $27.5 \mathrm{Aa}$ & $22.9 \mathrm{Bb}$ & $16.8 \mathrm{Bc}$ \\
\hline 1.00 & $160.2 \mathrm{Aa}$ & 126.1 Ab & $29.6 \mathrm{Bc}$ & $27.0 \mathrm{Aa}$ & $26.9 \mathrm{Aa}$ & $14.1 \mathrm{Cb}$ \\
\hline 0.75 & $119.5 \mathrm{Ba}$ & $73.4 \mathrm{Bb}$ & $40.8 \mathrm{Ac}$ & $27.5 \mathrm{Aa}$ & $22.3 \mathrm{Bb}$ & $19.0 \mathrm{Ac}$ \\
\hline \multicolumn{7}{|c|}{ Izabela } \\
\hline & \multicolumn{3}{|c|}{ Fresh weight of aerial part } & \multicolumn{3}{|c|}{ Fresh weight of roots } \\
\hline $\mathrm{L} \mathrm{min}^{-1}$ & $100 \%$ & $75 \%$ & $50 \%$ & $100 \%$ & $75 \%$ & $50 \%$ \\
\hline 1.50 & $97.0 \mathrm{Aa}$ & $90.5 \mathrm{Ab}$ & 43.4 Ac & $28.4 \mathrm{Aa}$ & $23.0 \mathrm{Bb}$ & $11.8 \mathrm{Bc}$ \\
\hline 1.00 & $77.0 \mathrm{Ba}$ & $48.8 \mathrm{Bb}$ & $22.2 \mathrm{Bc}$ & $29.4 \mathrm{Aa}$ & $25.2 \mathrm{Aa}$ & $11.8 \mathrm{Bb}$ \\
\hline 0.75 & $59.5 \mathrm{Ca}$ & $49.1 \mathrm{Bb}$ & $12.5 \mathrm{Cc}$ & $26.6 \mathrm{Ba}$ & $24.1 \mathrm{Ab}$ & $19.4 \mathrm{Ac}$ \\
\hline
\end{tabular}

*Means followed by the same lowercase letter in the row and uppercase in the column do not differ by Tukey test, $5 \%$ (para cada característica, médias seguidas por letras maiúsculas iguais na coluna e minúsculas na linha não diferem pelo teste de Tukey, 5\%).

flow rate $1 \mathrm{~L} \mathrm{~min}^{-1}$ and $75 \%$ of ionic concentration. Higher accumulation of fresh mass of roots for Izabela cultivar was observed in total ionic concentration and flow rates of 1.5 and $1.0 \mathrm{~L} \mathrm{~min}^{-1}$, as well as in flow rate $1.0 \mathrm{~L} \mathrm{~min}^{-1}$ and $75 \%$ of ionic concentration (Table 1).

Higher fresh mass of the aboveground part of 'Lucy Brown', cultivated in September at different flow rates (experiment 3 ), was observed, at flow rates higher than $1.0 \mathrm{~L} \mathrm{~min}^{-1}$. For 'Veneza', higher values for fresh mass were observed at a flow rate of $1.5 \mathrm{~L} \mathrm{~min}^{-1}$ (Figure 2). Generally speaking, for the increase of fresh mass of aboveground part among the tested cultivars, in the three experiments, 'Lucy Brown' showed higher values in comparison to 'Izabela' and 'Veneza'.

Fresh mass obtained for 'Lucy Brown', 'Izabela' and 'Veneza' are similar to ones obtained by Schmidt et al. (2002), Backes et al. (Helbel Junior et al., 2008), however, the results were lower than the ones obtained by Costa et al. (2001) in hydroponic cultivation. Helbel Junior et al. (2008), studying the mass gain of Vera cultivar (crisp) grown in nutrient solution of Furlani et al. (with total ionic concentration and in flow rates between 0.8 and $1.0 \mathrm{~L}$ $\mathrm{min}^{-1}$ concluded that the flow rate was a factor that did not influence the increase of fresh mass for crisp lettuce under hydroponic cultivation, a different result from the ones obtained in this work.

In relation to the ionic concentration of the solution, Cometti et al. (2008), cultivating lettuce of crisp group in $50 \%$ of ionic concentration of the nutrient solution, proposed by Furlani et al. the ones observed in this work. Nevertheless, these authors stated that the nutrient solution at $50 \%$ of ionic concentration might, somehow, result in variations in mass gain and in the yield of the lettuce crop, since this concentration is close to the limit of dilution.

It is noteworthy that the ionic concentration and the flow rate of the nutrient solution are determinant variables of the nutrient availability and water absorption by the plants in hydroponic systems (Costa et al., 2001; Martinez, 2002), and the interrelationship of these variables can alter the growth and the partition of assimilates in the plants; it can also be inferred that the ionic concentration of the nutrient solution is a determinant component in regulation of the stomatal opening (through the osmotic potential), in photosynthetic efficiency, in the expansion of the leaves, in the leaf and 


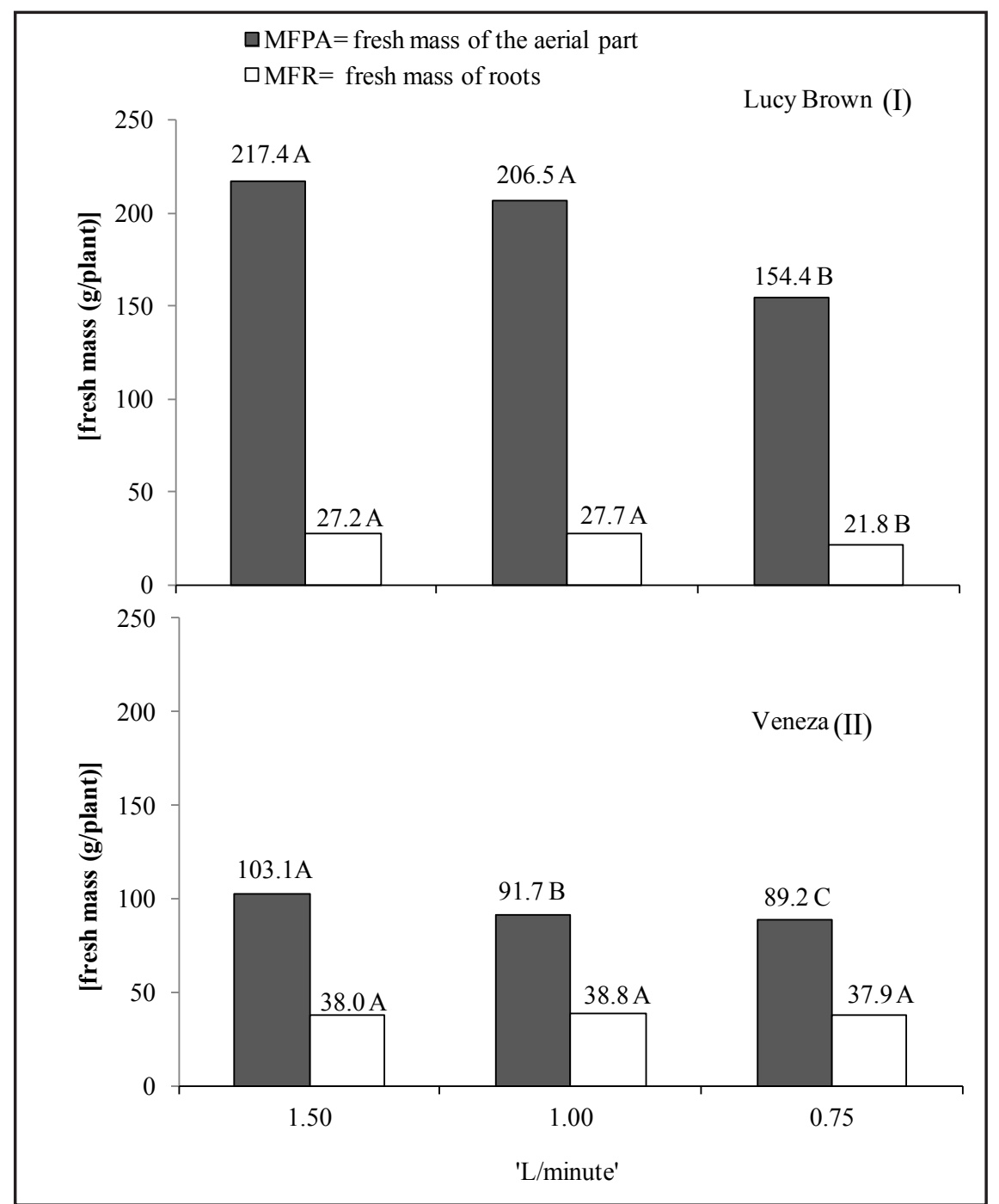

Figure 2. Fresh weight of aerial part and roots $\left(\mathrm{g}_{\text {plant }}{ }^{-1}\right)$ of lettuce cvs. Lucy Brown and Veneza, grown under three hydroponic system flows in September 2006 (massa fresca de parte aérea e raiz $\left(\right.$ g planta $\left.^{-1}\right)$ de alface, cultivares Lucy Brown e Veneza, cultivadas em hidroponia com três vazões de solução nutritiva, no mês de setembro de 2006). *Means followed by the same letter did not differ by Tukey test (para cada característica, médias seguidas pela mesma letra não diferem pelo teste de Tukey). Seropédica, UFRRJ, 2006.

root growth, as well as in harvest index of crops cultivated in hydroponics (Beltrão et al., 1997; Costa et al., 2001). Huett (1994) highlights that the water and nutrient absorption by the plants is related to the ionic concentration of the nutrient solution and results regarding the accumulation of fresh mass are according to the appropriate osmotic potential of the nutrient solutions used for hydroponic lettuce (Filgueiras et al., 2002).

It is possible to infer that the increase of the flow rate is a factor that might have favored at lower temperatures low concentrations affect the root respiration, nutrient absorption and, consequently, the plant growth.

A general analysis of the data allows concluding that the application of nutrient solution at a flow rate of 1.5 $\mathrm{L} \min ^{-1}$, as well as $100 \%$ of ionic concentration is efficient to increase the fresh mass of the aboveground part for the cultivars Lucy Brown, Izabela and Veronica when grown in hydroponics.

\section{REFERENCES}

ANDRIOLO JL.1999. Fisiologia das culturas protegidas. Santa Maria: UFSM. 142p.

BACKES FAAL; SANTOS OS; PILAU FG; BONNECARRÈRE RAG; MEDEIROS SLP; FAGAN EB. 2004. Reposição de nutrientes em solução nutritiva para o cultivo hidropônico de alface. Ciência Rural 34: 1407-1414.

BELTRÃO J; TRINDADE D; CORREIA PJ. 1997. Lettuce yield response to salinity of sprinkle irrigation water. Acta Horticulturae 449: 623-627.

COSTA PC; DIDONE EB; SESSO TM; CANIZARES KAL; GOTO R. 2001. Condutividade elétrica da solução nutritiva e produção de alface em hidroponia. Scientia Agrícola 58: 595-597.

COMETTI NN; MATIAS GCS; ZONTA E; MARY W; FERNANDES MS. 2008. Efeito da concentração da solução nutritiva no crescimento da alface em cultivo hidropônicosistema NFT. Horticultura Brasileira 26: 252-257.

FERNANDES AA; MARTINEZ HEP; PEREIRA PRG; FONSECA CM. 2002. Produtividade, acúmulo de nitrato e estado nutricional de cultivares de alface em hidroponia, em função de fontes de nutrientes. Horticultura Brasileira 20: 195-200.

FILGUEIRA FAR. 2008. Novo manual de olericultura: agrotecnologia moderna na produção e comercialização de hortaliças. 3.ed. Viçosa: UFV. 421p.

FILGUEIRAS RC; TAKAHASHI HW; BENINI ERY. 2002. Produção de alface hidropônica em diferentes condutividades elétricas. Semina: Ciências Agrárias 23: 157-164.

FURLANI PR; SILVEIRA LCP; BOLONHESI D; FAQUIN V. 1999. Cultivo hidropônico de plantas. Campinas: IAC, 52p (Boletim Técnico 180).

HELBEL JUNIOR C; REZENDE R; FREITAS PSL; GONÇALVES ACA; FRIZZONE JA. 2008. Influência da condutividade elétrica, concentração iônica e vazão de soluções nutritivas na produção de alface hidropônica. Ciência e Agrotecnologia 32: 1142-1147.

HELBEL JÚNIOR CE; REZENDE R; SANTOS SH; FREITAS PSL; AZEVEDO TLF FRIZZONE JA. 2007. Soluções nutritivas, vazões e qualidade de alface hidropônica. Acta Scientiarum Agronomy 29: 291-295.

HUETT DO. 1994. Growth, nutrient uptake 
and tipburn severity of hydroponic lettuce in response to electrical conductivity and $\mathrm{K}:$ Ca ratio solution. Australian Journal of Agricultural Research 45: 251-267.

LUZ JMQ; GUIMAR ÃES STMR; KORNDÖRFER GH. 2006. Produção hidropônica de alface em solução nutritiva com e sem silício. Horticultura Brasileira 24: 295-300

MARTINEZ HEP. 2002. O uso do cultivo hidropônico de plantas para pesquisa. Viçosa: UFV. 61p.

RODRIGUES LRF. 2002. Técnicas de Cultivo hidropônico e de controle ambiental no manejo de pragas, doenças e nutrição vegetal em ambiente protegido. Jaboticabal: Funep/ Unesp. 762p.

SAEG. 2000. Sistema para Análises Estatísticas. Versão 8.0. Viçosa: Fundação Arthur Bernardes.
SCHMIDT D; SANTOS OS; BONNECARRÉRE RA; MARIANI AO; MANFRON PA. 2001. Desempenho de soluções nutritivas e cultivares de alface em hidroponia. Horticultura Brasileira 19: 122-126.

SOFFER H; BURGER DW. 1988. Effects of dissolved oxygen concentrations in aerohydroponics on the formation and growth of adventitious roots. Journal of the American Society for Horticultural Science 113: 218221. 